\title{
Mineral Extraction for Socio-Economic Transformation of Tanzania: The Need to Move from Papers to Implementation of Mining Policy and Law
}

\author{
Japhace Poncian (Corresponding author) \\ Assistant Lecturer, Department of History, Political Science and Development Studies \\ Mkwawa University College of Education, P. O. Box 2513, Iringa-Tanzania \\ E-mail: jponcian@muce.ac.tz; jponcian@yahoo.co.uk
}

Constantine George

Programme Officer, Research

REPOA

P.O. Box 33223, Dar es Salaam-Tanzania

E-mail: cgeorge@repoa.or.tz

Received: April 16, 2015 Accepted: May 4, 2015 Published: May 5, 2015

doi:10.5296/jsss.v2i2.7450 URL: http://dx.doi.org/10.5296/jsss.v2i2.7450

\begin{abstract}
Tanzania is endowed with vast quantities and types of resources whose extraction has been central to the country's economic growth. However, the challenge has been translating growth in extraction activities into inclusive and sustainable socio-economic development and transformation. Instead of being of benefit to all, mineral resource extraction has only served to put Tanzania into the map of foreign capital flows but with limited benefits to the local citizens. Drawing on academic literature, government policy and legal documents as well as other secondary materials, this paper examines challenges of translating resource extraction into inclusive and sustainable socio-economic development in Tanzania. It focuses on large scale gold mining and local content provisions. The paper argues that having in place a good policy and legal framework is nothing if it is not implemented to the benefit of local communities and the entire nation. There is, therefore, a need to move from papers to
\end{abstract}


implementation if mineral resource extraction is to be of any significance to socio-economic transformation. This is very significant especially now that Tanzania has a new mining sector legal and policy framework in place and is looking forward to making the most out of its recently discovered natural gas.

Keywords: Tanzania, mining, policy, law, implementation

\section{Introduction}

While natural resources of different types are abundant in Tanzania, their exploitation for sustainable socio-economic development and transformation remains a daunting challenge. Tanzania is known for being endowed with, among others, different mineral resources such as diamonds, gold, tanzanite, coal, and hydrocarbons. These mineral resources have been exploited for quite some time now. Their exploitation has contributed significantly to exports and to some extent, to Gross Domestic Product (GDP), employment opportunities, etc. For example, in the quarter ending December, 2013, mineral exports were the leading forex earners accounting for $\$ 539.4$ million $(33.6 \%$ ) of the total $\$ 1,606.8$ million (Bank of Tanzania, 2014a, p. 18). Moreover, the sector contributed 3.3\% to GDP growth in 2013 (a decline from 3.5\% in 2012) (Bank of Tanzania, 2014b, p. 3). Much of this contribution comes from gold mining which is the largest mining sub-sector in the country. Gold exports accounted for $50 \%$ of the total non-traditional exports in the financial year 2010/2011(Bank of Tanzania, 2012, p. 6).

The major challenge, however, has been translating these achievements into broad based and equitable benefits to all. Similarly, linkages between the mining sector and the wider economy have remained weak. Consequently, benefits from the sector have largely gone to few people with access and links to the sector. What is even more challenging is that this has not been due to lack of legal and policy instruments to make the harnessing of mineral resources beneficial to the national economy and to ordinary citizens. There have indeed been legal and policy provisions requiring that the sector be linked with the wider economy so that the majority Tanzanians would benefit from mineral resource extraction. Much of the academic discourse on mining in Africa has overly put blame on the legal and policy frameworks as if there was nothing good in them to make mining beneficial to all (see, among others, Campbel, 2003; Bush, 2008; Campbell, 2009; Economic Commission for Africa (ECA), 2011; Gajigo, Mutambatsere, \& Ndiaye, 2012). While this may contain some truth, the reality is that the failure of mineral extraction to deliver to development and related benefits is something that cannot be wholly blamed on poor policy and legal regimes.

This paper examines the challenges of translating resource extraction into inclusive and sustainable socio-economic development in Tanzania. It centres on the link between policy and legal documents and the actual practices on the ground. The focus is on large scale gold mining which is the largest mining sub-sector in the country in terms of foreign direct investment, mineral production and exports, and contribution to national economy. The paper draws on the repealed policy and legal framework so as to draw implications for the implementation of the current one. The rest of the paper is organised as follows. Following this introduction, section two presents local content provisions as stated in the Mineral Policy 
and Mining Act of 1997 and 1998 respectively. This is followed by an examination of the extent to which such provisions were legally enforced and/or implemented. Section four examines the reasons for why the government did not fully implement policy and legal provisions. Section five considers the implications of laxity in implementing past policy and legal provisions on the success of the current policy and legal framework. Finally, a conclusion is given at the end.

\section{Local Content Provisions in the Mineral Policy and Legal Framework}

Local content is one of the strategies used in many resource rich countries to ensure that resource extraction is beneficial to the majority. Local content is about the extent to which resource extraction activities generate further benefits through links with other sectors beyond the direct contributions (Tordo, Warner, Manzano, \& Yahya, 2013). The main purpose of local content requirements is to create jobs, promote enterprise development and accelerate the transfer of skills and technologies (IPIECA, 2011). This is why local content is used to refer to the added value a nation gets from its resource extraction through workforce development (employment and training of local workforce) and investment in supplier development (local procurement of services and goods, and development of supplies and services locally) (IPIECA, 2011, p. 1). Given its potential benefits, many resource rich countries include local content provisions in their resource extraction policies and laws. This is also the case in Tanzania.

Although the now repealed mineral sector policy and legal regime was criticised for not having enabled Tanzania to get the most from the extraction of its gold and other mineral resources, this does not mean that it did not contain some good provisions. The major purpose of the 1997 Mining Policy was to 'attract and enable the private sector to take the lead in exploration, mining development, mineral beneficiation and marketing'(United Republic of Tanzania, 1997, p. 8). Accordingly, the policy's aims, among others, were:

* Stimulating exploration and mining development;

* Ensuring that mining wealth supports sustainable economic and social development;

* Minimising or eliminating the adverse social and environmental impacts of mining; and

* Promoting and facilitating mineral and mineral-based products marketing arrangements (United Republic of Tanzania, 1997, p. 9).

To integrate the sector into the economy in order to create strong backward and forward linkages, the policy aimed to foster economic inter-dependence between mining and other sectors and ensure that benefits of mining accrue to the rest of the economy especially through maximising value addition (United Republic of Tanzania, 1997, p. 19). Several strategies to achieve this noble goal were identified, including the following:

* Developing the country's ability to provide essential inputs to the mining sector;

* Offering incentive schemes to promote mineral beneficiation;

* Promoting forward linkages through development of value adding activities; 
* Encouraging the acquisition of modern cost effective technologies to produce high quality mineral products for world markets; and

* Directing special efforts in promoting development and exploitation of industrial minerals (United Republic of Tanzania, 1997, pp. 19-20).

The policy also set strategies for human capital development and local community involvement and participation in mining activities. Strategies mentioned in the policy included:

* Encouraging and motivating foreign investors in mining to train Tanzanians in different skills;

* Encouraging and facilitating training in disciplines necessary for mineral sector's development;

* Requiring large scale mining companies to undertake social impact analyses on the communities and project areas and explicitly incorporate results in the project viability and draw up programmes for addressing negative impacts;

Establishing a framework for timely promotion of good relations with the population of mining localities;

* Encouraging mining companies to contribute to local economic development by using local inputs whenever this is economically viable;

* Facilitating the establishment of strategic partnerships between mining companies and the local communities (United Republic of Tanzania, 1997, pp. 20, 26).

The success of all these provisions would greatly be determined by the role played by the government. Consequently, the policy spelt out the role of the government, thus,

The Government's role in the mineral sector is to provide clear policy guidelines, stimulate and promote the sector's various players, and see to the sector's general development. Rather than directly engaging in productive activities, the Government will concentrate its efforts on being the sector's regulator, promoter, facilitator and service provider ... (United Republic of Tanzania, 1997, p. 27).

Thus, despite the weaknesses many critics have pointed out about the policy, it is clear that local content provisions were taken on board when drafting the policy document. Whether or not they were implemented is another issue. To give a legal base to the policy provisions, a Mining Act was enacted in 1998. The Act made provisions for prospecting for minerals, dealing in minerals and mining in Tanzania, and the allocation of mineral rights and the process for applying for tendering (Natural Resource Governance Institute, 1998). Section 38.4 of the Mining Act 1998 required the applicant for the Special Mining Licence (SML) (a licence granted for large scale mining projects), to, among others, provide details on employment and training of citizens of Tanzania. This was also made an obligation of the SML right holder in Section 44 (b). However, the Act did not provide provisions for other important areas such as the procurement of local goods and services, the involvement and 
participation of local communities, nor did it make a condition for SML right holders to process minerals for value addition before exporting them. Accordingly, this is where the root of the problem lies: the mismatch between policy contents, legal provisions and contractual provisions; the question of enforcement and implementation.

\section{Implementation of Local Content Provisions}

Having a good mining policy and code in place is one thing and implementing it is another. The now defunct policy and legal framework was successfully implemented especially in the area of creating conducive environment for investment in the mining sector and the attraction of significant foreign investment capital into the sector. Consequently, FDI inflows into the country increased from US \$232 million in the period from 1990 to 1995 to US \$ 1.3 billion in 1996 to 2000 (Rutaihwa \& Simwela, 2012, p. 175). This then increased to US $\$ 5.94$ billion in 2007 (Rutaihwa \& Simwela, 2012). During the period from 2000 to 2007 , over $60 \%$ of the growth in FDI inflows to the country was accounted for by mining (Rutaihwa \& Simwela, 2012). FDI inflows continued to increase beyond 2007. For example, from 2008 to 2011 FDI increased from USD 6,941.5 million to USD 9,278.1 million respectively (Tanzania Investment Centre, 2013, p. 18). The highest inflows were recorded in 2010 when USD 1,813.3 million was received, thanks to the global economic recovery and increased natural gas exploration activities (Tanzania Investment Centre, 2013, p. 18). Because of this, several large scale gold mining projects were opened. These included Golden Pride (owned by Resolute Ltd), Geita Gold Mine (owned by AngloGold Ashanti), Kahama Mining (owned by Barrick Gold Corporation), Afrika Mashariki (now North Mara Gold Mine owned by Acacia (formerly African Barrick), Buhemba Gold Mine, and Tulawaka Gold Mine.

Mineral exports have also increased, contributing to a reduction in the dominance of traditional exports. For example, while gold accounted for only $2 \%$ of total exports between 1997 and 1999, by 2007-2009, its contribution had jumped to 27\% (Magai \& Márquez-Velázquez, 2011, p. 9). The country has also been able to receive significant revenues from taxes and royalties, with an increase from USD 700,000 in 1997 to USD 26 million in 2006 (United Republic of Tanzania, 2008, cited in Magai \& Márquez-Velázquez, 2011, p. 11). In 2013 alone, Tanzania received USD 70.76 million as revenues arising from royalty payment by miners (a slight decline compared to USD 71.1 million realised in 2012) (Tanzania Minerals Audit Agency (TMAA), 2014, p. 16; TMAA, 2013, p. 19). As one report sumed up:

The more liberal and private-sector friendly polices [sic] pursued by governments since 1995 and for the mining sector from 1998 have produced a 9-year bonanza for the country. A number of large international mining companies have collectively invested a total of well over $\$ 2$ billion in the sector mainly in gold mining. ... this has made Tanzania the largest non-oil recipient of foreign direct investment in Africa after South Africa: easily out-distancing Kenya. From being on a par with coffee and the other main traditional exports 9 years ago, gold now earns the country $\$ 780$ million per annum $-700 \%$ more foreign exchange than coffee. Although still an infant industry ... it already contributes more than 3\% to total national tax revenues (circa \$100 million per annum) (International 
Council on Mining and Metals , 2009, p. 2).

Similarly, mining activities have brought in significant revenues in terms of royalties and taxes paid by mining companies to government. As figure 1 shows below, the revenues accrued to the government as companies' payment of royalties have increased from a paltry of United States Dollar (USD) 1.6 million in 2001 to 40.5 million in 2010 mainly due to increased gold production and exports (Muganyizi, 2012, p. 18). Moreover, taxes collected by government from mining companies have increased from USD 2.1 million in 1999 to 71.6 million in 2010, thus accounting for $2.2 \%$ of the total tax revenue collected by the Tanzania Revenue Authority (TRA) (see figure 2 below) (Muganyizi, 2012, p. 18). This reflects how mining has moved from just an insignificant sector to one that contributes relatively better to the country's economy even though its contribution remains far below expectations.

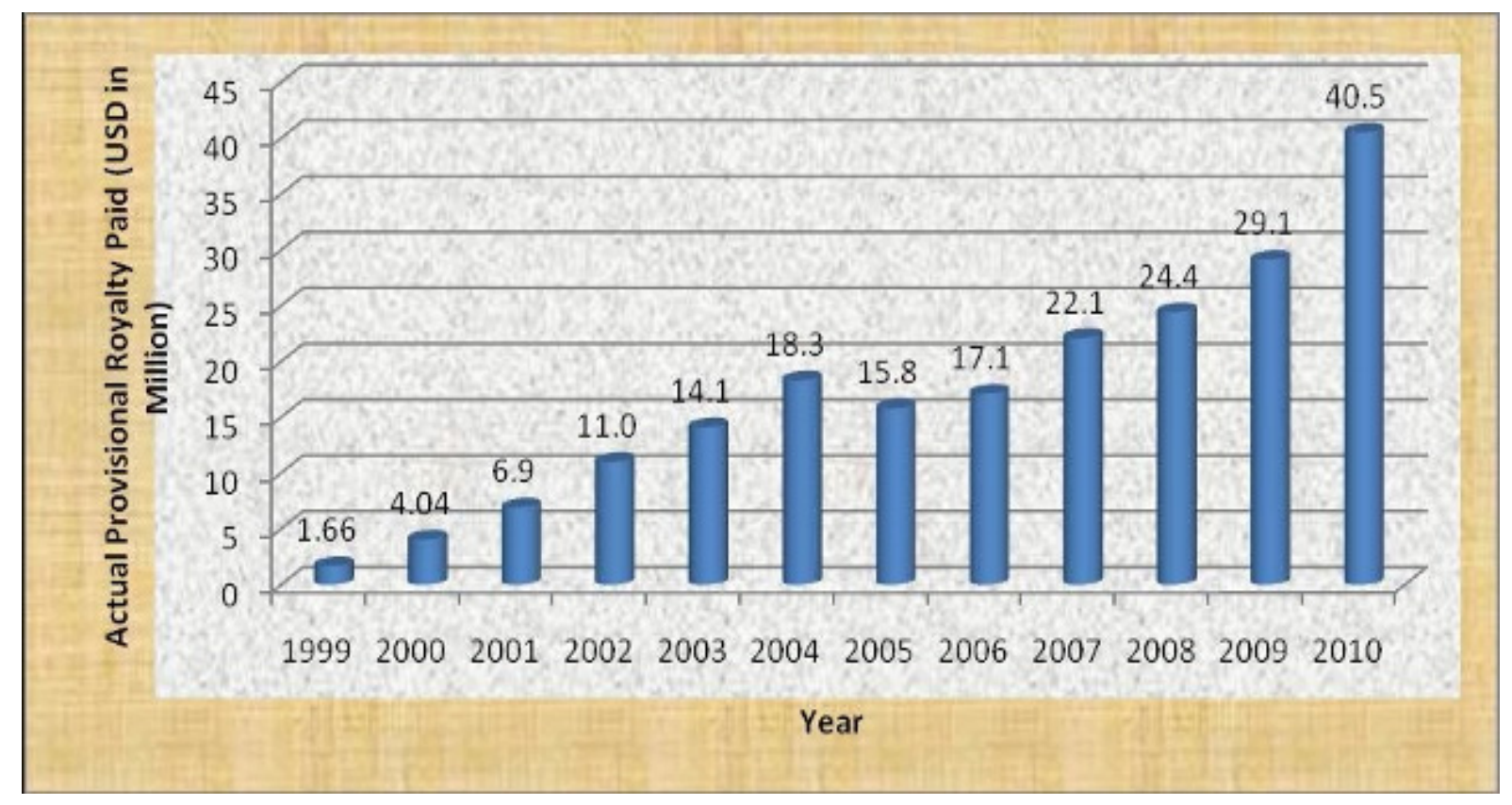

Figure 1. Provisional Royalties paid by Large Scale Gold Mines, 2001-2010

Source: Ministry of Energy and Minerals, cited in Muganyizi (2012, p. 18). 


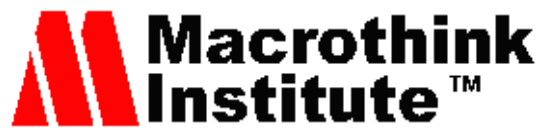

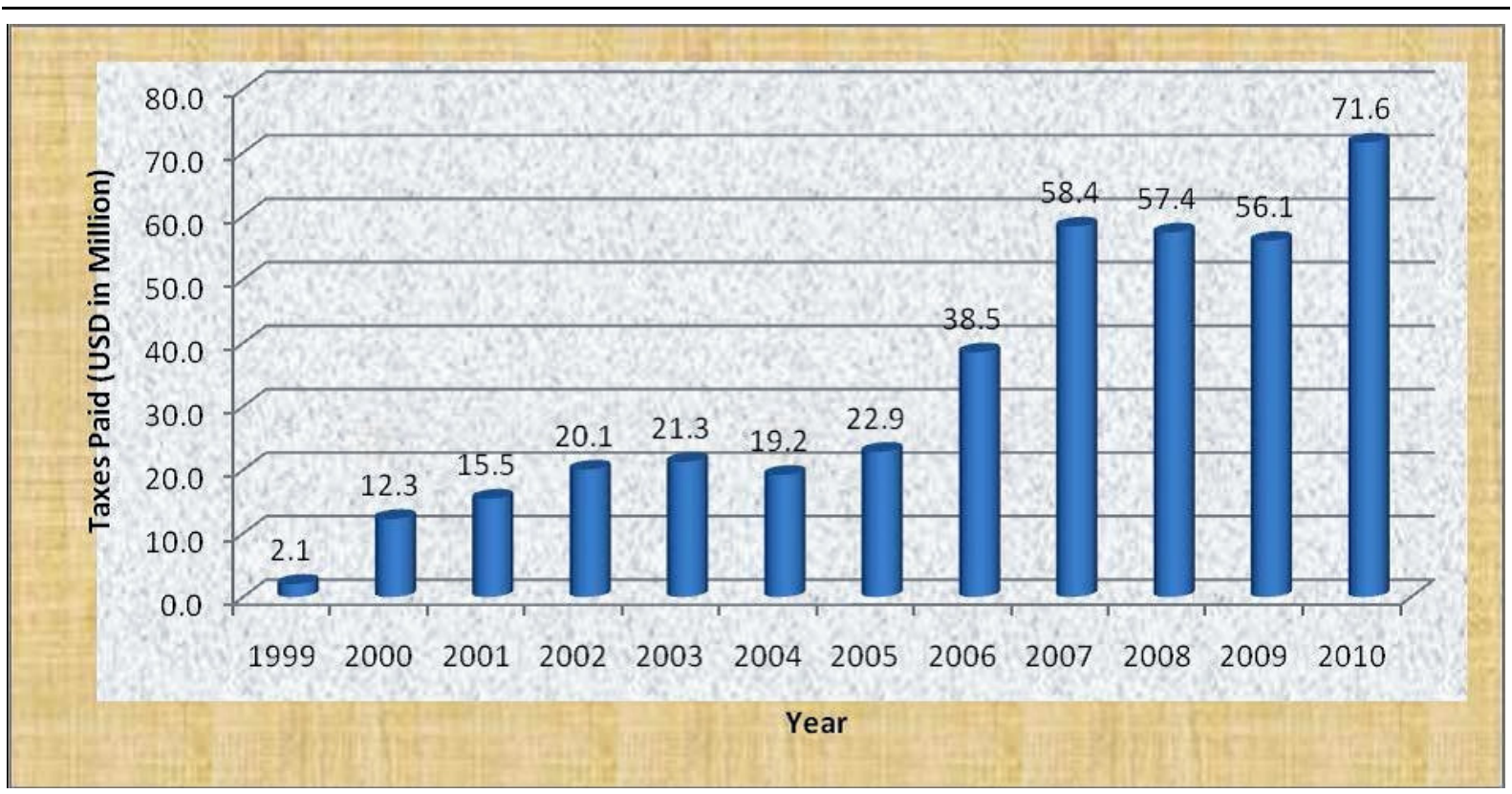

Figure 2. Taxes paid by large scale mining companies, 1999-2010

Source: TRA and MEM as cited in Muganyizi (2012, p. 19).

Mining companies have also been investing some of their profits in corporate social responsibility (CSR) to increase their visibility, acceptance and social thickness in the communities they operate. Some notable contributions have been in the areas of education, health, water and roads. Acacia (formerly African Barrick Gold) set a community development fund, the Maendeleo Fund, in 2011 as part of its CSR strategy and has since spent over $\$ 18$ million to finance projects in education, health and sanitation, water, infrastructure, livelihoods, and others (African Barrick Gold, 2014). Although mining companies CSR projects have covered many areas, much emphasis has been on education and health (Concern for Development Initiatives in Africa (ForDIA), 2012). For instance, of the total $\$ 11.5$ million spent by African Barrick Gold on community development projects in 2013, \$5.4 million (about 47\%) was spent on education and health (African Barrick Gold, 2014 , p. 9). Other areas supported by the fund have included support to communities affected by disasters and entrepreneurship. For example, in 2010 the African Barrick donated 50 million Tanzanian shillings to victims of floods in Bukombe district, launched a disaster fund, and spent 22.6 million to send to college 30 entrepreneurs from Kakola village, Bugarama ward in Kahama district (Tanzania Daima, 30 April 2010, cited in ForDIA, 2012, p. 19). However, it is reported that majority of communities in mining areas do not consider corporate social responsibility programmes to be adequate and that such programmes do not respond to the needs and priorities of the communities (ForDIA, 2012).

In spite of the achievements mentioned above, mining activities have generally failed to live up to the promise of development. Benefits accruing from large scale mining have only benefitted a few people with much of the proceeds retained by investors. The only area where majority Tanzanians would have benefitted from mining activities is local content which 
entails linking mining activities with wider economy. However, this is the area which remained untapped throughout the first phase of mining liberalisation in Tanzania. In fact one of the reasons for the repeal of the policy and legal framework in 2009 and 2010 respectively was that the economy and people of Tanzania were not benefitting significantly from mineral extraction. Although the 1997 Mining Policy emphasised the linkage between mining sector and other sectors of the economy (for example, local procurement of goods and services) the practice was different. Large scale gold mining companies were blamed for procuring goods and services from outside the country while these were locally available. According to one investigative journalist:

There's another lie being circulated by the pimps of the IMF [International Monetary Fund] and WB [World Bank] in the mining sector, and this pertains to the claim that a big chunk of the billions in the procurement of facilities was spent locally. The truth of the matter is that eighty per cent of mining supplies were dominated by foreign-based suppliers who have subsidiaries in the country.

Anglogold Ashanti, for instance, used an Australian company to provide catering services to its gold mine for about a decade while importing beef, though it had about 80 per cent local employees. Of course, there are some businesses which are granted to local suppliers, but a big chunk of the money went to Australia, South Africa, Canada and the United Kingdom (Mgamba, 2012, paras. 40-41).

This is very well confirmed in the Presidential mining review committee report which reports that:

In this industry [mining] operations are many; services and people are many as well. However, most citizens told the committee that some investors hire these services from outside the country. It is said that even some food stuff is also imported and same is available in the country (United Republic of Tanzania (URT), 2008, p. 44).

Even with employment and training of citizens of Tanzania, the situation has not been good. Although large scale gold mining has created employment opportunities to Tanzanians, the conditions under which they work and the pay they get are not good relative to their foreign counterparts. According to a government commissioned report, the Bomani Report:

... there is a big difference between the salaries paid to citizens compared to foreigners even though they hold the same qualifications. For example in one given mine a foreigner is paid six million (Tsh. 6,000,000) per month and a citizen with the same post and qualifications is paid only eight hundred thousand (TZS.800, 000) per month (URT, 2008, p. 37).

While the Mining Act 1998 required applicants for SML to present detailed plan on the employment and training of citizens of Tanzania, a review of contracts by Policy Forum revealed that the contracts did not bind miners to employ local Tanzanians. They were free to employ as many expatriates as possible and the employees were entitled to numerous rights which allowed them to repatriate their proceeds, thus creating a very thin linkage with the local economy. For example, part of the Tulawaka and Buzwagi contracts reads: 
Provided that Pangea, its contractors and sub-contractors, substantially comply with all applicable Tanzanian laws, including completing the application procedures and pay the requisite fees, Pangea, its contractors and sub-contractors are free to employ, without restriction non-Tanzanians and the GoT [Government of Tanzania] will expeditiously grant such persons all necessary work permits, visas, and passes for this purpose. Any such expatriate employees (and contractors and sub-contractors) involved in the mine development and mining operations are entitled to repatriate their salaries. Upon first arrival, they are permitted to import tax-free personal and household effects, including one vehicle. However, such items cannot be re-sold in Tanzania except in accordance with the Government regulations. At the termination of their employment, they are further entitled to repatriate their pension monies, balance of their salaries, as well as personal and household effects including those previously imported into Tanzania as well as purchased within Tanzania, provided that they have remitted their income taxes (Policy Forum, 2008, p. 4).

Furthermore, the Policy provision for involvement and participation of local communities in the mining projects was also not implemented as it was not included in the Mineral Development Agreements signed between the government and Tulawaka, Buzwagi, and Geita Gold Mines (Policy Forum, 2008). Similarly, provisions for local capacity building in terms of training local people were not included in the contracts (Policy Forum, 2008). As such, the government failed itself to realise its policy and legal provisions. It was thus not that the Policy and Act did not at all provide for such important provisions, it was rather the reluctance of the government to translate what was on paper into actual practice. Given this, one is left with a critical question to ask: why did the government shun away from implementing what it planned to do?

\section{Explaining the Government's Laxity in Implementing Policy and Legal Provisions}

The failure of the government to implement its policy and legal provisions regarding local content has largely been blamed on two factors: the government's limited capacity to enforce the provisions and pressures from the International Financial Institutions (IFIs) on making the sector's policy and code internationally competitive. Scholars believe that a range of reforms implemented by Tanzania and other resource rich African countries significantly constrained the capacity of the state (both financially and technically) to oversee the sector and enforce regulations (Campbell, 2003; Campbell, 2008a; Campbell, 2008b; Campbell, 2009). This incapacity of the state created a huge gap between the state and mining companies' capacity. This made large scale miners to be so powerful and command favour so much that some scholars have argued that the companies have had surrogate sovereignty (Kline, 2006). Because state capacity was constrained and mining companies were too powerful, the local state chose to be complacent in the name of promoting national economy, though at the expense of rights of citizens:

... to ensure a healthy national economy the state enters into an intimate relation with big corporations... the state readily adopts such policies as ensuring a conductive [sic] environment for the making of super profit, making public resources accessible to private 
exploitation, limiting and repressing the demands of workers, communities, the poor etc. (Owugah, 2001, pp. 52-53).

There is also an argument that benefits from mining have been limited and the government was unable to implement many of its policy and legal provisions regarding local content because of pressures from the IFIs. This pressure whether real or perceived was making the government to do all it could to create an environment that would not scare investors. The fact that there were many other countries rich in natural resources was making matters worse. Consequently, the state drafted mining contracts which were in favour of miners prompting some observers to dub this as a 'race to the bottom' (Akabzaa, 2004; Tax Justice Network-Africa and Action Aid, 2012). The fact that the government of Tanzania took so long to review its mineral policy and legal framework despite countless reports about losses sustained by Tanzania is a clear reflection of the fears of scaring investors within the government circles:

... there is a fear that too much reform will upset the companies, the donors and the international institutions, none of which is championing significant, or indeed any, fiscal reform. The government is to a large extent hamstrung by arguments about 'international competitiveness' and the over-riding priority to continue to attract foreign investment (Curtis \& Lissu, 2008, p. 30).

While these factors are pertinent and explain what might have been happening, they do not go far enough to tell us why the government drafted a policy containing some good local content provisions only to end up dropping some of them in the Mining Act and the subsequent Mineral Development Agreements. The 1997 Mining Policy was formulated in an environment where the government was cognizant of international competition, and the policy was actually in line with the IFIs prescriptions. The disparity between what was written in the Policy, the Act and the mining contracts had more to do with the complacency of the government than just the pressures from IFIs and state capacity.

Without implementing the provisions, it remains unclear how the government thought to make mining beneficial not only to the economy but also to the citizens of Tanzania. Was it just an issue of mining companies lobbying the government to abandon its policy provisions? For a government that was very determined to implement its policy and legal provisions, this should not have been an issue. Such complacency and/or lack of political will to implement legal and policy provisions should be the one to be blamed for why mining hasn't been of anticipated benefits. This however, is not to rule out the role of skewed mining sector reforms adopted by Tanzania and other resource rich countries of Africa. What this means is that we should be cautious of the way we attribute mining's limited benefits to regulation and reforms. Understanding this is critical for any success of recent regulations.

\section{Implications for the Implementation of the Current Policy and Legal Framework}

Following the unsatisfactory performance of the mining sector in terms of its contribution to national development and benefits accruing to the citizens, the government repealed the 1990s policy and legal framework. Consequently, a new Mining Policy was formulated in 
2009 and a new Mining Act enacted in 2010. The current Mineral Policy seeks to address the challenges of mineral extraction in Tanzania as experienced from the first generation mineral sector reforms. The focus of the Policy is 'to increase the mineral sector's contribution to the GDP and alleviate poverty by integrating the mining industry with the rest of the economy' (United Republic of Tanzania, 2009, p. 9).

On a similar note, the Mining Act 2010 provides a legal basis for enforcement and implementation of the Policy provisions. For example, the policy provisions on integration of mining with other sectors, government and citizens' participation in mining activities, adequate land compensation and relocation schemes, provision of employment and training to citizens of Tanzania, and promoting mineral value addition activities (United Republic of Tanzania, 2009) are well captured in Part IV, Divisions B and D, and Part X of the Mining Act Number 14, 2010. For example, Article 44 (d) of the Act states that the content of the granted Special Mining Licence (SML) should include conditions on, among others, the environmental management plan, employment and training of citizens of Tanzania and succession plan, and procurement plan of the goods and services available in Tanzania. It also clearly stipulates that application for renewal of an SML must show, among others, how the conditions of the licence were implemented.

Looking at the policy and legal provisions, it appears that the current policy and legal framework has taken on board the challenges of large scale gold mining in the country. However, having a good policy and legal framework is not a guarantee that the sector will automatically benefit the country and its people, nor does it guarantee that the good local content provisions will be achieved (Poncian, 2012). As the above analysis shows, there is more to getting the best share from natural resource extraction than just having a policy and legal framework with good provisions. This however, should not be taken to mean that a good policy and legal framework is not important. From the experience of Tanzania's implementation of the 1997 and 1998 Mining Policy and Act, it is obvious that good policy and legal provisions are as good as nothing if they are not implemented to their last letter. It is good that the current legal regime is consistent with the policy provisions as differentiated with the previous one in which some of the policy provisions were not captured in the Mining Act.

As such, making the current policy and legal framework work to the benefit of the country and make the sector achieve the policy and legal goals and objectives depends on how the government seriously implements the policy and legal provisions. It requires that emphasis be put on practical and determined implementation of the provisions rather than just continuing to brag of having a good policy and code. It is important to bear in mind that the current policy and legal framework does not make Tanzania less competitive in the global business of investment attraction; so its implementation should not in any way be curtailed by perceptions and/or fears of scaring potential investors.

The experience of first phase liberalised mineral policy and law should be a yardstick as Tanzania looks ahead of getting the best from its natural resources. That until 2014 no single company had started implementing new tax and royalty rates as per the 2010 Act itself tells of 
the challenge of putting in practice policy and legal framework provisions (Binala, 2014). Moreover, that it is only one company, Acacia, that has cross-listed its shares in the Dar es Salaam Stock Exchange as per the current Act provisions tells more of the challenge that lies ahead of Tanzania's quest to make citizens have ownership over mining activities (Dar es Salaam Stock Exchange (DSE), 2014). Thus, policy and legal frameworks are good only when implemented to their last letter. Policy and legal statements on papers are as good as nothing if not implemented.

\section{Conclusions}

Getting the best from the extraction of minerals in Africa continues to be a challenge. Much of the academic discourse on mining and why it has not benefitted Africa as expected has overly focused on inadequacy of mining codes and the weak state capacity to surveil and control multinational corporations. This paper has, however, argued that there is more to Africa's limited benefits than just weak codes and state capacity. The paper has argued that limited benefits from mining are partly due to the deliberate failure of the government to implement all the policy and legal provisions.

Similarly, the disparity between what the policy directs and what is contained in the mining codes means that benefits to be accrued from mining as per intended policy objectives/statements are not realised. The case in point here is the disparity in local content provisions between the 1997 Mineral Policy of Tanzania and the Mining Act 1998. While a law is supposed to provide a legal base for the implementation of the policy provisions/objectives (especially the mining policy which depends on law to be implemented, at least in the Tanzanian case), the Mining Act 1998 left out some of the important local content provisions such as local procurement of goods and services, participation and involvement of local communities in mining, etc. Even where these were mentioned in the Act, they were not reflected in the Mining Agreements signed between the government and the miners.

One important conclusion to be made about all this is a clear reflection of government's failure to translate what is written in the policy and legal documents into actual practice. Moreover, the failure to put in place codes which translate policy provisions into legally enforceable provisions shows the extent to which the same government/parliament which drafted and ratified a policy turned its back on some provisions when enacting a law to enforce the policy. Thus, the challenge is not that we don't have good policies and laws in place, but rather our failure to translate them into practice. Having a good policy and legal framework in place is in itself not enough to guarantee that mineral resources will be exploited for the benefit of the country and its people. A good policy and legal framework must be accompanied by serious and determined implementation efforts especially when negotiating mining contracts with large scale miners and following up on the agreed terms of the contracts. The current policy and legal framework is as good as nothing if the good provisions contained in it are not translated into practical implementation on the ground. As such, making gold mining contribute significantly to socio-economic transformation of Tanzania is only possible if the government seriously enforces and implements the sector's 
policy and legal provisions, especially those related to local content.

\section{References}

African Barrick Gold. (2014). Maendeleo Fund Annual Report 2013. Retrieved April 16, 2015, from http://www.acaciamining.com/ /media/Files/A/Acacia/documents/sustainability/ABG\%20M aendeleo\%20Brochure\%20-\%202013.pdf

Akabzaa, T. (2004). African Mining Codes: a Race to the Bottom. Retrieved January 27, 2015, from http://www.choike.org/nuevo_eng/informes/2400.html

Bank of Tanzania. (2012). Monthly Economic Review, December 2012. Dar es Salaam: Bank of Tanzania.

Bank of Tanzania. (2014a). Economic Bulletin for the Quarter Ending December, 2013. Dar es Salaam: Bank of Tanzania.

Bank of Tanzania. (2014b). Annual Report, 2013/2014. Dar es Salaam: Bank of Tanzania.

Binala, J. (2014, October 11). Tanzania Seals New Tax Deal with Mining Firms. Retrieved April 16, 2015, from The East African: http://www.theeastafrican.co.ke/news/Tanzania-seals-new-tax-deal-with-miners--drops-15pcwaiver-/-/2558/2483144/-/8xnhsjz/-/index.html

Bush, R. (2008). Scrambling to the Bottom? Mining, Resources and Underdevelopment. Review of African Political Economy, 35(117), 361-366. http://dx.doi.org/10.1080/03056240802410968

Campbel, B. (2003). Factoring in Governance is notenough: Mining Codes in Africa, Policy Reform and Corporate Responsibility. Minerals and Energy, Raw Materials Report, 18(3), 2-13. http://dx.doi.org/10.1080/14041040310019129

Campbell, B. (2008a). Reform Processes in Africa: Issues and Trends. Paper presented at the 2nd International Study Group (ISG) Meeting, United Nations Economic Commission forAfrica, Addis Ababa, 19-21 May.

Campbell, B. (2008b). Regulation and Legitimacy in the Mining Industry in Africa: Where does Canada stand? Review of African Political Economy, 35(117), 367-385. http://dx.doi.org/10.1080/03056240802410984

Campbell, B. (2009). Introduction. In B. Campbell, Mining in Africa: Regulation and Development (pp. 1-24). London: Pluto Press.

Concern for Development Initiatives in Africa (ForDIA). (2012, September 10). Corporate Social Responsibility (Mining Sector) in Tanzania: Geita District Case Study Report. Retrieved April 16, 2015, from http://www.publishwhatyoupay.org/resources/corporate-social-responsibility-mining-sector-t anzania 
Curtis, M., \& Lissu, T. A. (2008). A Golden Opportunity? How Tanzania is Failing to Benefit from Gold Mining, 2nd Edition. Retrieved January 28, 2015, from https://www.kirkensnodhjelp.no/.../a-golden-opportunity-2nded.pdf

Dar es Salaam Stock Exchange (DSE). (2014). Listed Companies. Retrieved April 16, 2015, from http://www.dse.co.tz/content/listed-companies

Economic Commission for Africa (ECA). (2011). Minerals and Africa's Development: The International Study Group Report on Africa's Mineral Regimes. Retrieved May 3, 2015, from http://www.africaminingvision.org/amv_resources/AMV/ISG\%20Report_eng.pdf

Gajigo, O., Mutambatsere, E., \& Ndiaye, G. (2012, March). Gold Mining in Africa: Maximizing Economic Returns for Countries. African Development Bank Group Working Paper Series, No. 147. Retrieved May 3, 2015, from http://www.afdb.org/fileadmin/uploads/afdb/Documents/Publications/WPS\%20No\%20147\% 20Gold\%20Mining\%20in\%20Africa\%20Maximizing\%20Economic\%20Returns\%20for\%20 Countries\%20120329.pdf

International Council on Mining and Metals. (2009, July 8). Tanzania: Mining's Socio-Economic Contribution. Retrieved April 14, 2015, from http://www.icmm.com/document/626

IPIECA. (2011). Local Content Strategy: A Guidance Document for the Oil and Gas Industry. Retrieved January 20, 2015, from http://www.ipieca.org/publication/local-content-strategy-guidance-document-oil-and-gas-ind ustry

Kline, J. (2006). MNCs and Surrogate Sovereignty. The Brown Journal of World Affairs, 13(1), 123-133.

Magai, P. S., \& Márquez-Velázquez, A. (2011, August). Tanzania's Mining Sector and Its Implications for the Country's Development. Berlin Working Papers on Money, Finance, Trade and Development, Working Paper No. 04/2011. Retrieved January 27, 2015, from www.lai.fu-berlin.de\%2Fhomepages\%2FAlejandro_Marquez\%2FPublikationen\%2Fwp_201 1_04_Magai-Marquez_Tanzanias-Mining-Sector.pdf

Mgamba, R. (2012, April 8). How WB and IMF pushed Dar into large-scale mining. Retrieved January 27, 2015, from IPP Media: http://www.ippmedia.com/frontend/?1=40313

Muganyizi, T. K. (2012, August). Mining Sector Taxation in Tanzania: ICTD Research Report 1. Retrieved April 15, 2015, from http://www.ictd.ac/en/publications/mining-sector-taxation-tanzania

Natural Resource Governance Institute. (1998, June 30). Tanzania Mining Act. Retrieved December 15, 2014, from http://www.resourcegovernance.org/training/resource_center/tanzania-mining-act 
Owugah, L. (2001). Oil Transnationals, State and Development in The Oil Producing Communities of the Niger Delta. In T. W. Africa, Mining, Development and Social Conflicts in Africa (pp. 45-76). Accra: Third World Network Africa.

Policy Forum. (2008). The Demystification of Mining Contracts in Tanzania. Retrieved December 12, 2014, from www.policyforum-tz.org/files/demystification.pdf

Poncian, J. (2012). Tanzania's New Mining Act: Will it Change the 'Rules of the Game' in Large Scale Gold Mining? . Unpublished MA Dissertation, University of Leeds, United Kingdom.

Rutaihwa, J., \& Simwela, A. (2012). Econometric Analysis of FDI in the Mining Sector to Tanzania's Export Capacity. International Journal of Academic Research in Business and Social Sciences, 2(10), 174-191.

Tanzania Investment Centre. (2013). Tanzania Investment Report 2012: Foreign Private Investment and Investor Perception. Retrieved January 27, 2015, from www.tic.co.tz\%2Fmedia\%2FTIR2012\%2520Main\%2520Report\%2520for\%2520Web.pd

Tanzania Minerals Audit Agency (TMAA). (2014). Annual Report 2013. Retrieved January 25, 2015, from http://www.tmaa.go.tz/publications/view/tmaa-annual-report-2013

Tax Justice Network-Africa and Action Aid. (2012). Tax Competition in East Africa: a Race to the Bottom? Retrieved January 27, 2015, from www.actionaid.org/sites/files/actionaid/eac_report.pdf

The Mining Act 1998. (1998). Tanzania.

The Mining Act, No. 14, 2010. (2010). Tanzania.

TMAA. (2013). Annual Report 2012. Retrieved January 25, 2015, from http://www.tmaa.go.tz/publications/view/tmaa-annual-report-2012

Tordo, S., Warner, M., Manzano, O., \& Yahya, A. (2013). Local Content Policies in the Oil and Gas Sector. Washington D.C.: The World Bank. http://dx.doi.org/10.1596/978-0-8213-9931-6

United Republic of Tanzania. (1997). The Mineral Policy of Tanzania. Retrieved January 2, 2015, from www.tzonline.org/pdf/themineralpolicyofTanzania.pdf

United Republic of Tanzania. (2008). Report of the Presidential Mining Review Committee to Advise the Government on Oversight of the Mining Sector. Vol. 2. Retrieved January 20, 2015, from http://www.policyforum-tz.org/bomani-report-popular-version

United Republic of Tanzania. (2009). The Mineral Policy of Tanzania. Retrieved January 28, 2015 , from https://mem.go.tz/wp-content/uploads/2014/02/0014_11032013_Mineral_Policy_of_Tanzani a_2009.pdf 


\section{Copyright Disclaimer}

Copyright reserved by the author(s).

This article is an open-access article distributed under the terms and conditions of the Creative Commons Attribution license (http://creativecommons.org/licenses/by/3.0/). 